\title{
ワイヤ張力の機械的拘束方向への干渉を利用した ワイヤ駆動システムの剛性増加法
}

\author{
木 野 仁*1 矢部茂*2 島 本 武 史 ${ }^{* 2}$ 川 村 貞 夫*2

\section{Stiffness Increase Method of Wire Driven Systems} \\ using Interference of Driving Directions and Mechanical Constraint Directions
}

\author{
Hitoshi Kino $^{* 1}$, Sigeru Yabe ${ }^{* 2}$, Takeshi Shimamoto ${ }^{* 2}$ and Sadao Kawamura ${ }^{* 2}$
}

\begin{abstract}
Parallel wire driven systems have many advantages such as high speed and safety to humans. When the motion of the system is restricted less than 6 D.O.F., mechanical constraints are utilized to fix the unnecessary D.O.F. and the remained freedoms of the system are driven by the parallel wire mechanism. The mechanical constraints should be light for realization of high speed or safety to humans. As the results, the stiffness of the directions made by mechanical constraints decreases and oscillation occurs in many cases. In this paper, we propose a stiffness increase method basing on nonlinear stiffness of the mechanical constraints and the wire drive units. In the proposed method, interference of wire tension with mechanical constraints must be effectively used. In order to obtain an appropriate interference pattern, an algorithm to design wire directions is also proposed. Finally, the effectiveness of the proposed method is demonstrated through several experimental results.
\end{abstract}

Key Words: Wire Driven System, Mechanical Constraint, Stiffness

\section{1.はじめに}

一般にワイヤ駆動は，可動部分の慣性を小さくできるので， 高速運動の実現や人間との機械的親和性に優れている [1]〜 [5]. しかし，ワイヤ特有の問題もいくつか存在する。ワイヤや構造 部分などから生じる低剛性が，大きな問題の一つである．筆者 らはワイヤ駆動システムの剛性を増加し, 高速運動停止時の振 動抑制の目的で, 7 本ワイヤを用いた 6 自由度のパラレルワイ ヤ駆動システムを提案し, 内力によって剛性を増加させる方法 を示している [4] [5]. この方法によれば，ワイヤの張力発生方 向には, 内力によって効果的に剛性を増加できることが実験的 にも確認されている.

しかし, 実際のアプリケーションでは, 対象物体の 6 自由度 すべてを制御する必要がない場合も多い。そのような場合には， 不要な自由度を機械的に拘束して，必要な自由度をワイヤ駆動 することになる。その際，ワイヤ駆動自由度には，前述の内力 による剛性増加方法が利用できる。一方，機械的拘束方向には， 振動抑制については検討されていない。これは, 機械的拘束部 には高精度な加工と組み立てと, 十分な剛性が保証されている

原稿受付 2000 年 11 月 24 日

*1 福岡工業大学工学部

$* 2$ 立命館大学理工学部

${ }^{* 1}$ Faculty of Engineering, Fukuoka Institute of Technology

${ }^{* 2}$ Faculty of Science and Engineering, Ritsumeikan University
と考えられていたためである。しかし，一般に工学的現実を考 えると，より安価に簡便に製作されることが望ましい，さらに， 高速運動や人間との機械的親和性の目的を強調するためには, 機 械的な拘束自体も軽量とする必要がある。これに伴って, 機械 的拘束物体の機械的ガ夕や低剛性の問題が生じる。そこで本論 文では, 機械的拘束部の機械的ガ夕を減少させ, 剛性を増加さ せる方法を検討する. 本論文では以下, 用語として,「剛性増加」 を同じ值の力によって生じる変位を小さくする意味に用いる.

具体的には，多くの場合では機械拘束部に，2 章で述べるよ うな非線形剛性要素が存在することを利用し, ワイヤ張力を意 図的に機械的拘束方向に干涉させ, システムの剛性を増加する 方法を提案する。この方法ではワイヤの配置を工夫することで 対象物の機械拘束自由度の振動抑制が可能であり, ワイヤ駆動 系での新たな設計指針を与えることができる、本論文では, 基 本的な考え方と実用的な設計法を提案するとともに, 簡単な実 験により提案する方式の有効性を示す.

\section{2. 基本概念と問題設定}

\section{1 変形と剛性増加}

本論文で提案する設計方法の基本的アイディアを示す. Fig. 1 (a)に示されてように, 平面内を動く質点で表現される 対象物体にはワイヤが連結されており，機械的拘束を利用して 不要な自由度 $(y$ 方向) を機械拘束しているとする。このとき, 機械的拘束物体抢よびワイヤには, Fig. 2 に見られるような非 
島本武史川村貞夫

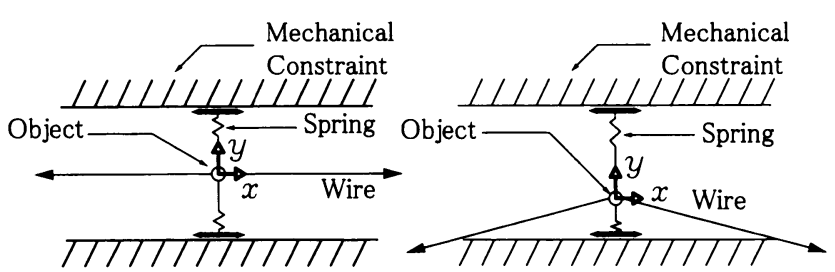

(a)

(b)

Fig. 1 Basic concept

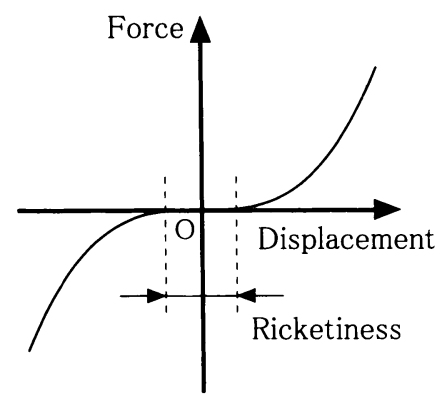

Fig. 2 Non-linear elasticity

線形な特性が存在すると仮定する，すなわち，変位の増加に伴っ て剛性が増加する特性である．実際のシステムにこのような特 性があるかは，後の実験結果などから示すこととする．本論文 では以後, Fig. 2 に示される機械的ガ夕を含む特性を非線型剛 性特性と呼ぶ. Fig. 1 ではこの非線形特性をスプリングで表現 している.そこで, Fig. 1(b) のようにワイヤの張力方向を調節 し, $y$ 方向に駆動を干涉させると, 非線形剛性特性より, $y$ 方 向の剛性が増加する. 本論文では, この特性を利用して, ワイ ヤ駆動における機械拘束自由度の剛性増加方法を論じる.

もちろん, 対象物体や機械的拘束に応力をかけた状態を作る ことや, 応力の増加・減少を繰り返すことが, 対象物体や機械 拘束物体の材料にどのように影響するかなども，実用上の問題 となろう。ただし, 本論文では, 多自由度系に関する設計法に 主眼を置き，この問題には触れないこととする。

\section{2 システムに関する仮定}

提案する剛性増加法を利用すれば，ワイヤ駆動システムの運 動中も, 高剛性を保てる可能性がある. しかし, 議論を簡略化 するために，運動停止時における振動を抑制することを目的と する. 解析では以下の仮定を設ける.

（1）ワイヤには幅がなく, ワイヤの張力発生方向回りのモーメ ントは考えない.

(2) 対象物体の 6 自由度のうち, 少なくとも 1 自由度は機械 拘束されているとする。

（3）座標系の設定は，機械拘束方向と駆動方向が分離できるよ うに行う。

（4）拘束面, 拘束軸などの摩擦は無視できる.

（5）機械的拘束物体は完全剛体ではなく微小変形する.

（6）仮定（5）の変形は, Fig. 2 に見られるような, 変位の増 加に伴って剛性が増加する非線形特性を有する。

（7）以下の論議ではワイヤ方向などの表現に座標系が利用され る。ただし，拘束物体の変形から生じる座標系の変化は，
ワイヤ方向 (力方向) の違いを論議するオーダーに対して 無視できる大きさと考える.

（8）通常, 剛性行列の非対角項が存在する.これらの項も仮 定（6）と同様の非線形性を有していると考えることもで きる、しかし，ここでは論議を簡略化するために, 剛性行 列の対角成分のみの効果によって, 剛性を増加させると考 える。

（9）仮定（7）とかかわって, 本来, 力方向が変化する場合は, ワイヤの内力による剛性効果が知られている $[6] \sim[8]$. し かし, 力方向の変化が微少であるので, この効果は無視 する.

（10）アクチュエータは任意の力を発生可能とする.

（11）重力を含む外力による影響はないものとする.

\section{3. 千渉ワイヤ配置による剛性增加法}

\section{1 空間定義と力学的関係式}

効果的に機械拘束部の剛性増加を行うための, ワイヤ配置に ついて考察する. 説明の簡略化のために以下では多自由度系と して完全拘束型のパラレルワイヤ駆動システム $n(n<6)$ 自由 度を制御する場合を取り扱う。対象物体上には座標系が設置され ており, 対象物体の並進自由度 $(x, y, z)$, 回転自由度 $(\alpha, \beta, \gamma)$ の計 6 自由度のうち, $k(=6-n)$ 自由度を機械拘束する. 使 用するワイヤ本数は最小ワイヤ本数 $n+1$ 本とする。このとき, ワイヤ張力によって発生する力ベクトルを $f(6 \times 1)$ とすると, 次式で与えられる。

$$
\begin{gathered}
f=W \alpha_{t} \\
W=\left[w_{1} \cdots w_{n+1}\right] \\
w_{i}=\left[\begin{array}{c}
p_{i} \\
c_{i} \times p_{i}
\end{array}\right]=\left[\begin{array}{c}
p_{i} \\
r_{i}
\end{array}\right]
\end{gathered}
$$

ここに,

$W \in R^{6 \times(n+1)}:$ ワイヤ行列

$w_{i} \in R^{6}:$ ワイヤ行列 $\mathrm{W}$ の $i$ 番目の列ベクトル（ワイヤベクト ル )

$p_{i} \in R^{3}: i$ 番目ワイヤの方向単位ベクトル $\left(\left\|p_{i}\right\|=1\right)$

$c_{i} \in R^{3}: i$ 番目ワイヤの座標原点からワイヤ装着位置までのべ クトル

$r_{i}=c_{i} \times p_{i}:$ モーメントベクトル

$\alpha_{t}=\left[\alpha_{t 1} \cdots \alpha_{t(n+1)}\right]^{T}:$ ワイヤ張力ベクトル

$\alpha_{t i}: i$ 番目ワイヤの張力

とする. 従来の研究 $[5]$ では, この発生力 $f$ がすべて駆動力で ある場合を扱っていた。ここではワイヤ張力からの発生力を駆 動力と拘束力の両方に利用する.ただし，ワイヤは押すことが できず，常に引っ張り方向にしか張力を発生できないので，ワ イヤ張力ベクトル $\alpha_{t}$ は， $\alpha_{t i}>0(1 \leq i \leq n+1)$ を常に満足 しなければならない.

さて，ここで，駆動力と拘束力を明確にするために以下の考 察を行う. 駆動方向と拘束方向は, 対象によって設計者があら かじめ決定する。このとき，前述の仮定（3）より，機械拘束方 向と駆動方向とが分離できるように座標系が設定されている. 例えば, 並進・回転の 6 自由度を $(x, y, z, \alpha, \beta, \gamma)^{T}$ としたとき 
に, $z, \beta, \gamma$ 方向を機械拘束するとすれば，機械拘束された各方 向を基本ベクトルとした時に張る空間は $(x, y, 0, \alpha, 0,0)^{T}$, 各 駆動方向によって張られる空間は $(0,0, z, 0, \beta, \gamma)^{T}$ と表され, 完全に分離できるものとする。したがってこれらの空間は互い に直交補空間となる。

ここで, 駆動力ベクトル $\tau(n \times 1)$ と拘束力ベクトル $\xi(k \times 1)$ は次式で表す。

$$
\begin{aligned}
& \tau=S_{d} W \alpha_{t} \\
& \xi=S_{c} W \alpha_{t}
\end{aligned}
$$

上式において, 行列 $S_{d}(n \times 6), S_{c}(k \times 6)$ はそれぞれ, 駆動 方向, 機械拘束方向の基本単位ベクトルを行に持つ行列である. これらの行列には, 次の関係が成立している。

$$
S_{d}^{T} S_{d}+S_{c}^{T} S_{c}=I
$$

ただし， $I$ は $6 \times 6$ の単位行列である。前述の機械拘束例の場 合では,

$$
\begin{aligned}
S_{d} & =\left(\begin{array}{llllll}
1 & 0 & 0 & 0 & 0 & 0 \\
0 & 1 & 0 & 0 & 0 & 0 \\
0 & 0 & 0 & 1 & 0 & 0
\end{array}\right) \\
S_{c} & =\left(\begin{array}{llllll}
0 & 0 & 1 & 0 & 0 & 0 \\
0 & 0 & 0 & 0 & 1 & 0 \\
0 & 0 & 0 & 0 & 0 & 1
\end{array}\right)
\end{aligned}
$$

となる。式 (4), 式 (5), 式（6）より，式（1）は

$$
f=S_{d}^{T} \tau+S_{c}^{T} \xi=\left(S_{d}^{T} S_{d}+S_{c}^{T} S_{c}\right) W \alpha_{t}=W \alpha_{t}
$$

となっていることが理解される.ここで行列 $S_{d} W$ は発生力 $\tau$ に 直接的に作用寸る駆動力を表している.したがって, 行列 $S_{d} W$ は以下の Vector Closureの条件を常に満足しなければならな い[10].

V.C. 条件 $1 \operatorname{Rank}\left(S_{d} W\right)=n$

V.C. 条件 2 次式を満たすべクトル $\boldsymbol{\beta}_{t}=\left[\boldsymbol{\beta}_{t 1} \ldots \boldsymbol{\beta}_{t(n+1)}\right]^{T}$ が存在する.

$$
S_{d} W \beta_{t}=0
$$

ただし, $\boldsymbol{\beta}_{t i}>\mathbf{0}$ (foranyi) または $\boldsymbol{\beta}_{t i}<\mathbf{0}$ (foranyi)

一方, 式 (5) の行列 $S_{c} W$ の働きについては, 従来考えられ ていなかった，そこで, 本論文ではこの部分を剛性の増加に利 用する，前述した仮定より，式（5）の拘束力ベクトル $\xi$ の非 零值を有する自由度には，ワイヤ張力が機械拘束自由度に干涉 力を与えていることを意味し，非線形剛性特性より，その自由 度の剛性が増加できることを意味する。また，成分の絶対值が 大きいほど，高い剛性効果を得ることができる.

\section{2 ワイヤ配置の考察}

3.2 .1 すべての拘束方向に力を発生するワイヤベクトルの 条件

ここでは, 機械拘束自由度のすべての剛性を増加させるワイ ヤベクトルについて検討する。対象物体は位置姿勢を与えられ， かつ, 静止した状態であるとし, 各ワイヤの対象物との接点, お よびワイヤ方向は自由に決定できるとする。これは, 実システ

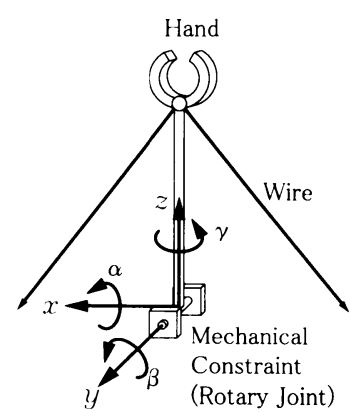

Fig. 3 Constrained wire driven system

ムにおいて，アクチュエータの配置を自由に決定できることを 意味する.すなわち, 前述の V.C.の条件を満足する限りは残っ た行列 $W$ の要素は自由に設定できるとする.

機械的拘束の剛性を増加させるためには，拘束力を発生させ ればよい，すべての拘束方向に力を発生させるためには，ワイ ヤ張力ベクトル $\alpha_{t}$ の各要素は正であるので, 行列 $S_{c} W$ の各 行ベクトルに, ゼロでない要素が存在し, かつ, その符号が各 行について同じであれば，要素間の相殺が起こらず，すべての 拘束力方向に拘束力を与えることができる。実際には，対象物 体の運動と共に，ワイヤの方向が変化する．これによって行列 $W$ の要素の值も変わるので, 一般には運動範囲のすべてについ て符号をチェックする必要がある。また，必ずしも各行について の符号が同一でない場合でも, 行列 $S_{c} W$ のゼ口空間に属さな いように張力 $\alpha_{t}$ を調整することができる.しかし，ワイヤべ クトルの変化や張力の大きさに依存して, 拘束力発生の可能性 が決定されるので，一般的に論議することは難しい，また，同 じワイヤ配置でも目標駆動力 $\tau_{d}$ を実現するために張力ベクト ルを変化させると， $\xi$ の值の大小に影響を及ほす。しかし，こ こでは拘束方向に力を発生できるかを定量的にのみ論じること とする，そこで，ここでは以下の十分条件を与える。

\section{すべての機械拘束方向の剛性を增加させるワイヤ配置十分条件}

式（5）の行列 $\boldsymbol{S}_{\mathbf{c}} \boldsymbol{W}$ の各行ベクトルに, ゼロでない 要素が存在し，しかも，その要素の符号が各行につい て同じである.

\section{2 .2 実用的なワイヤ配置設計法}

前項では，すべての拘束方向に剛性増加の条件を与えた。し かし，この条件を満足できる解が，一般の多くの対象で存在す る保証はない，一方，実用的観点からは必ずしも，すべての拘束 方向に拘束力を発しなくともよい場合が多い，例えば，Fig. 3 に示されるように，制御対象物体がロッド形状などで機械拘束 部と手先位置に距離があるときでは, 機械拘束された自由度の うち, 特に $\alpha$ 方向の低剛性より生じる振動現象は手先位置で増 大されるため，手先の情報に基づくフィードバックではシステ ムが不安定に陥る可能性がある。このような場合， $\alpha$ 方向の剛 性を増加させるだけで，十分な効果を得られる場合が多い。そ れゆえ, 拘束自由度のうち限定された自由度のみについて, 提 案する方法によって剛性を増加させることも有効となる。 そこ で, 本項では限定された拘束自由度について有効なワイヤ配置 
を求めるアルゴリズムを提案する.

まず，限定される自由度を以下のように記述する。式 (5) の 拘束力 $\xi(k \times 1)$ より注目する拘束力 $\hat{\xi}(m \times 1)$ を選定する.た だし， $m \leq k$ である. 行列 $S_{c}(k \times 6)$ と同様に必要な自由度の みに 1 の要素をもつ行べクトルによって行列 $S_{m}(m \times k)$ を作 り, 以下を得る。

$$
\hat{\xi}=S_{m} \xi=S_{m} S_{c} W \alpha_{t}=W_{c} \alpha_{t}
$$

ただし， $W_{c}=S_{m} S_{c} W$ とする。これと対応して，駆動自由度 についても

$$
\begin{gathered}
\tau=S_{d} W \alpha_{t}=W_{d} \alpha_{t} \\
W_{d}=S_{d} W
\end{gathered}
$$

としておく，適切なワイヤ配置を求めるために以下のアルゴリ ズムを提案する.

アルゴリズム

（1）機械拘束された対象物体の位置姿勢を一つ定める.

（2）駆動部とベースを適当な刻み幅によって空間を分割し，各 点をワイヤ端点位置の候補する.

（3）駆動部の一つのワイヤ端候補と, ベース部の一つのワイヤ端 候補を結んだ直線をワイヤ候補の一つとする．また， $n+1$ 個のワイヤ候補を一組のワイヤ配置候補とする.

（4）前の（3）のワイヤ候補に関して，駆動力自由度について Vector Closure 条件をチェックする.

（5）行列 $\boldsymbol{W}_{c}$ の各行について，以下を成立することをチェック する.

（a）少なくとも一つはゼロでない要素が存在する.

（b）ゼロでない要素はすべて同一符号を持つ.

（6）ワイヤ端点の各候補について, (3)〜（5）の手順を繰り返す．

（7）以上のチェックを可動範囲すべてに対して行い，ワイヤ配

\section{置の解を求める.}

上述したアルゴリズムでは，複数のワイヤ配置解が存在する 可能性がある。複数のワイヤ配置解が得られた場合では, シス テムに適するワイヤ配置解を絞り込み，最終的に一つに決定し なけれならない。その際には各ワイヤの外界との干渉や可動範 井，手先剛性などの評価が基準となる。しかしながら, 現時点 ではこれらの基準に対し，総合的な評価関数を決定することは きわめて困難である。したがって, 最終的なワイヤ配置解の絞 り込みは，個々の目的に応じて行うものとする。

次に Fig. 3 の例について，このアルゴリズムに基づいて，ワ イヤ配置を決定してみよう。制御対象物体は Fig. 3 に示される ようにロッド形状とし，ロッドの片端は機械拘束部材を介して ベース部に固定されている。また，もう一方の片端にはエンド エフェクタを装着することを想定する。ただし，パラレルワイ ヤ駆動システムの特性を生かし, 高速運動性や人間親和性を重 視するために，軽量のロッドを使用する．ワイヤは 2 本とし， 駆動自由度は $\beta$ 回転の 1 自由度, 残りの自由度のすべてが機械 拘束されている。本例では回転 $\alpha, \gamma$ に関して有効なワイヤ配 置を求めることとする。 $\gamma$ 回転は, 問題とならない場合も多い. しかし，本研究では，2リンク以上をシリアルに連結すること も考えているので $[11]$, その際には $\gamma$ 回転の変形も位置精度に

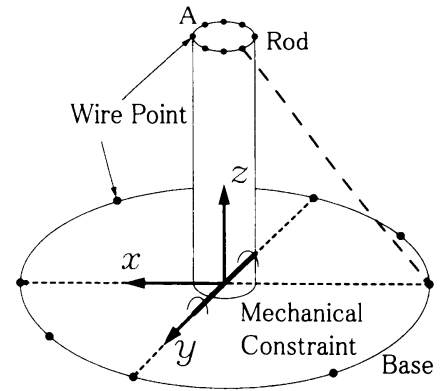

Fig. 4 Candidates of wire points

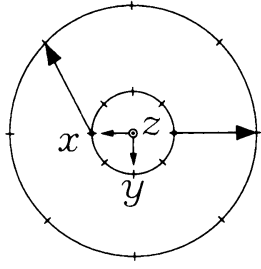

(a)

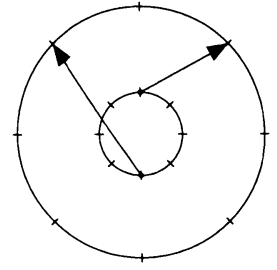

(b)
Fig. 5 Candidates of wire location

大きく影響する。そのために，ここでは， $\alpha$ と $\gamma$ 回転を対象と する.

・アルゴリズム（1）より，ベース部平面 $(x-y)$ に関して ロッドが垂直で静止した状態を考える（Fig.4）。

・次にワイヤ端点の位置候補を決定する（アルゴリズム $(2))$. この場合では, 軽量ロッドを使用し, ロッド端 $\mathrm{A}$ にエンド エフェクタを装着することを想定している。そこで，手先 A での剛性を高くするために，Fig. 4 に示されるように， 対象物に結合させるワイヤ端の候補をロッド端 $\mathrm{A} に$ に集中さ せる、したがって，ここでは，円柱縁上の 8 点を候補とし た。一方，ワイヤと外界との干渉する空間を極力少なくす るためと可動範囲を広くするために，ワイヤ配置を凸形状 としたい。そこで，ベース部のワイヤ出口に候補について は，ロッドを中心としたベース上の円を $\pi / 4$ 刻みで分割 し，円周上の 8 点とした。ただし，ベース上の円の半径は ロッド長さと同一とした。

- 2 本のワイヤ候補をワイヤ配置候補とし，すべてのワイヤ 配置候補について，アルゴリズム (4), (5) をチェックし, すべての条件を満足するものを解とする.

この場合のアルゴリズムより得られたワイヤ配置の解は, 一 意ではなく複数存在する. ワイヤ配置の解の例を, Fig. 5 に示 す. Fig. 5 ではロッド上部 A 端から原点方向にワイヤ端候補を 投影した図である。

\section{4. 剛性増加実験}

\subsection{1 自由度 2 本ワイヤ実験装置}

前章の例で取り扱った 1 自由度 2 本ワイヤシステムを用い て，提案する剛性増加法について実験を行った。実験システムは Fig. 6 に示されるように，ステンレス製のロッド，ワイヤ，ア クチュエー夕，機械拘束部，ベース部から構成される. 制御対象 


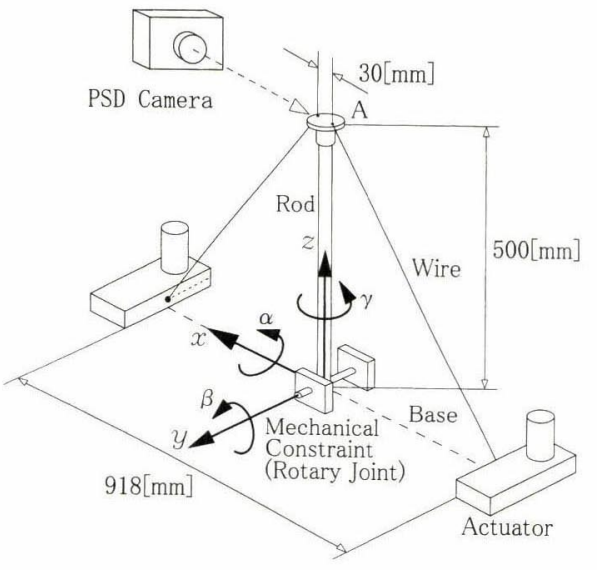

Fig. 6 Experimental system
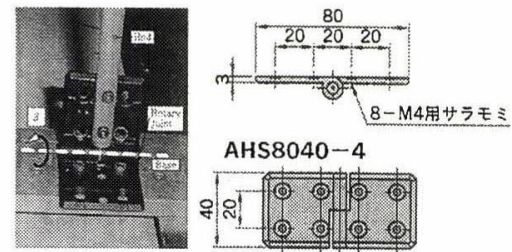

AHS8040-4

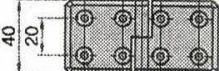

Fig. 7 Mechanical constraint

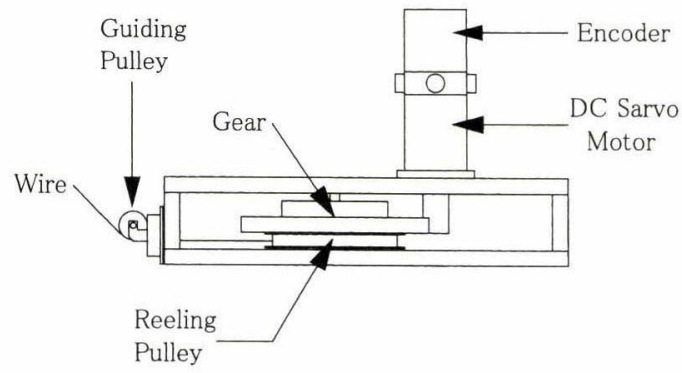

Fig. 8 Actuator

物体であるロッドは外径 $10[\mathrm{~mm}]$, 内径 $8[\mathrm{~mm}]$, 長さ $500[\mathrm{~mm}]$ を有した中空丸棒を用いている，片方の端が機械拘束されてお り，もう片端にはワイヤ 2 本が結合している。機械拘束部には 軽量化を図るために Fig. 7 に示されるように 1 軸の回転機構 を有した機械部材を使用しており，ロッドは拘束軸を中心に $\beta$ 方向の回転 1 自由度の制御が可能である。機械拘束部材は株式 会社ミスミ製アルミ蝶番（AHS8040-4）を用いた。材質は軸部 ( $\phi 5[\mathrm{~mm}])$ は SMC435 相当の材質, プレート部の材質はアル ミ合金ダイカスト 12 種である. なお, Fig. 7 の右図は株式会社 ミスミのご好意による.アアクチュータはFig. 8 のように，巻 き取りプーリ，小型ガイドプーリ，DCサーボモータから成る。 DC サーボモータは $60[\mathrm{~W}]$ の出力を有し, エンコーダを付属し ている，ワイヤは直径 $1[\mathrm{~mm}]$ のステンレス製を使用している.

実験システムは対象物体の 6 自由度のうち, $x, y, z, \alpha, \gamma$ の自由度を機械拘束し, $\beta$ 回転を制御する。

\section{2 実験結果}

4.2.1 静的剛性増加実験

はじめに, $\alpha, \gamma$ 方向の剛性増加実験ををそれぞれ別々に行う.

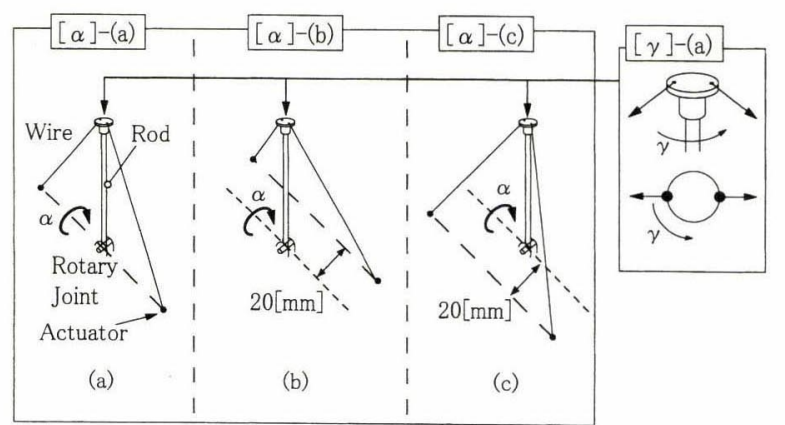

Fig. 9 Wires locations for $\alpha$ experiments

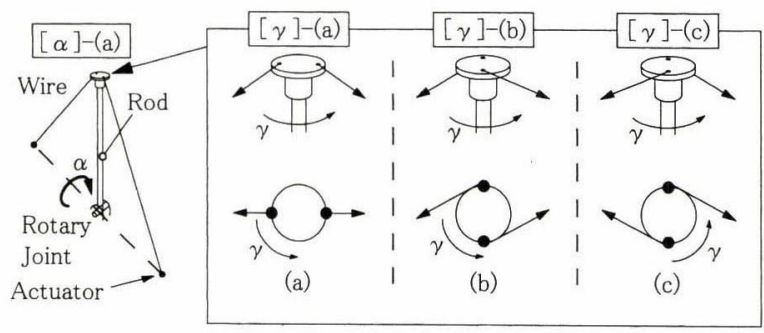

Fig. 10 Wires locations for $\gamma$ experiments

$\alpha$ 方向の㓮性害験に関しては Fig. 9 $(\alpha-\mathrm{a})-(\alpha-\mathrm{c})$ に示される 3 種類のワイヤ配置を準備した。ただし, ロッド先端 $\mathrm{A}$ のワイヤ 配置は常に $\gamma$ 方向に干涉力を生じないようにしてある $(\gamma-\mathrm{a})$. Fig. $9(\alpha-\mathrm{a})$ ではワイヤの駆動が $\alpha$ 方向に干渉のない状態であ り, $(\alpha-b)$ では正方向に干渉, $(\alpha-\mathrm{c})$ では負方向に干渉した配 置である。この三つのワイヤ配置について， $\alpha$ 方向に負荷トル クを与え, レーザー変位計を用いて手先部 A の変位を測定し, 点 Aの微少変位加 $\alpha$ の回転変位に変換する.

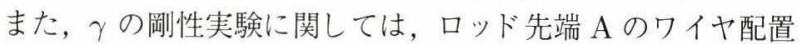
について, Fig. $10(\gamma-\mathrm{a})-(\gamma-\mathrm{c})$ の 3 種類を準備した。このと き, $\alpha$ 方向には干渉力を生じさせていない $(\alpha-a)$. 先の実験同 様， $(\gamma-\mathrm{a})$ ではワイヤの駆動が $\gamma$ 方向に干渉無し， $(\gamma-\mathrm{b})$ では 正方向に干渉， $(\gamma-\mathrm{c})$ では負方向に干渉した配置である。この 三つのワイヤ配置について, $\gamma$ 方向に負荷トルクを与え, ポテ ンショメータを用いて, 手先位置 A での回転 $\gamma$ の変位を測定 する。

剛性増加実験の予備的実験として, ロッド単体の剛性特性と ロッドに機械拘束部材を付加した状態での $\alpha$ および $\gamma$ 方向の剛 性特性をそれぞれ調べた。この二つ実験ではロッド先端にワイヤ を接続しておらず，張力を与えることができない、ロッド単体の 実験では，機械拘束部材が接合する側の端をボルトにてベース部 に固定している，予備実験では，ロッドを鉛直に静止させた状態 在保ち，各方向に負荷トルクを与え，変位を測定した．負荷トル クは $\alpha$ 方向に関しては $0 \rightarrow-0.6 \rightarrow 0 \rightarrow 0.6 \rightarrow 0[\mathrm{Nm}]$ と徐々 に変化させ, $\gamma$ 方向については $0 \rightarrow-0.4 \rightarrow 0 \rightarrow 0.4 \rightarrow 0[\mathrm{Nm}]$ と徐々に変化させた。これらの予備実験の $\alpha$ 方向の実験結果を

Fig. 11 に， $\gamma$ 方向の実験結果を Fig. 12 に示す、ロッド自体 の剛性に対し，機械拘束部材を付加した場合では，強い非線型 特性が観測できる.特に $\alpha$ 方向の非線型特性は機械的ガ夕に大 


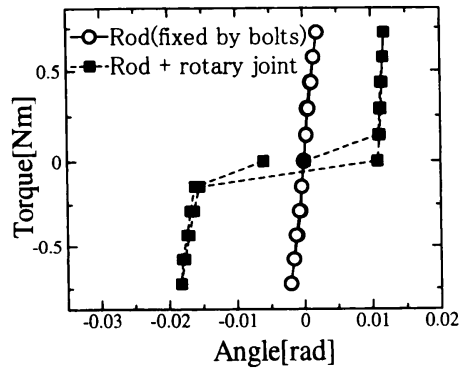

Fig. 11 Preliminary experiments of $\alpha$ direction

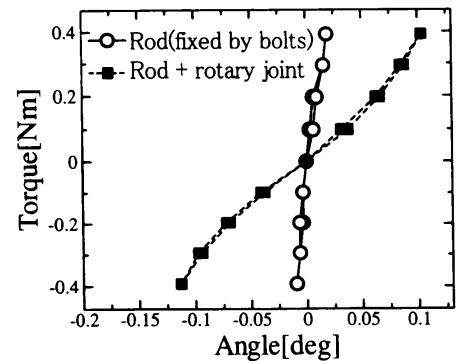

Fig. 12 Preliminary experiments of $\gamma$ direction

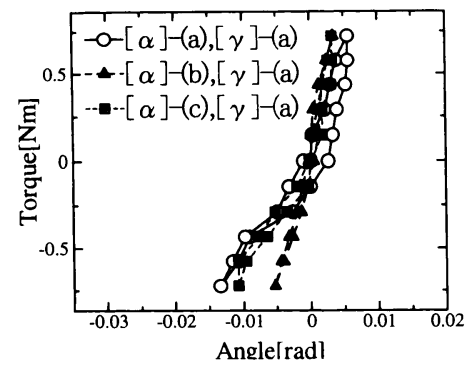

Fig. 13 Static experimental results of $\alpha$ (Fig. 9 System)

きく依存するものと推測される。

実際にワイヤを配置して行った剛性増加実験では，初めにワ イヤに釣り合い内力 $(\alpha=(113.4[\mathrm{~N}], 113.4[\mathrm{~N}]))$ を与え, ロッ ドを鉛直に静止させた状態を保った。その後, 各方向に負荷卜 ルクを与え，変位を測定した．負荷トルクは $\alpha$ 方向に関しては $0 \rightarrow-0.6 \rightarrow 0 \rightarrow 0.6 \rightarrow 0[\mathrm{Nm}]$ と徐々に変化させ, $\gamma$ 方向に ついては $0 \rightarrow-0.4 \rightarrow 0 \rightarrow 0.4 \rightarrow 0[\mathrm{Nm}]$ と徐々に変化させた

$\alpha$ 方向の剛性実験結果を Fig. 13 に, $\gamma$ 方向の剛性増加実験 をFig. 14 に示す。なお，横軸に变位を，縦軸に負荷トルクを 表している. 実験結果から, 駆動力を干渉させているワイヤ配 置 (b)，(c)の方が干渉のないワイヤ配置 (a)よりも剛性が増加 し，ロッド自体の剛性特性に近づいているのが分かる.

次に， $\alpha, \gamma$ 方向を同時に干涉させるワイヤ配置として， Fig. 15 のワイヤ配置を用いて, 同様に静的な剛性增加実験 を行った。ワイヤ配置は $\alpha$ 方向に負方向, $\gamma$ 方向に負方向の干 涉力を与えている。 これは前章で求めた， $\alpha$ と $\gamma$ 回転両方の剛 性を増加させるためのワイヤ配置解の一つである（Fig. 5 (b)). このワイヤ配置について, $\alpha$ 方向の剛性増加実験結果を Fig. 16 に, $\gamma$ 方向の剛性実験結果を Fig. 17 に示す. 比較のために干 涉力を与えていないワイヤ配置（ $\alpha-\mathrm{a}, \gamma-\mathrm{a})$ も同時に示す。 $\alpha$,

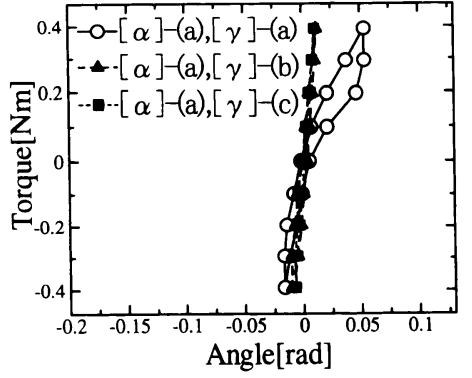

Fig. 14 Static experimental results of $\gamma$ (Fig. 10 System)

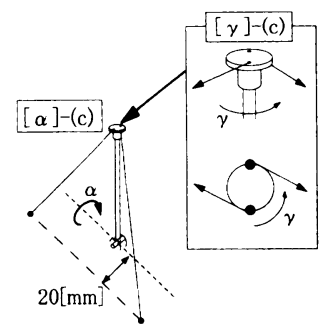

Fig. 15 Wires location to increase $\alpha$ and $\gamma$ stiffness

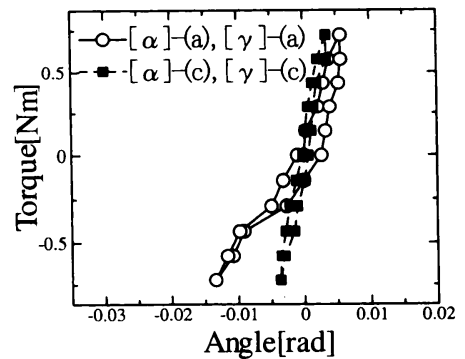

Fig. 16 Static experimental results of $\alpha$ (Fig. 15 System)

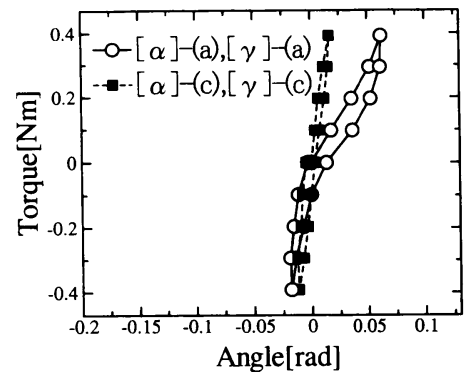

Fig. 17 Static experimental results of $\gamma$ (Fig. 15 System)

$\gamma$ 方向を同時に干渉させた場合でも先の実験同様，おのおのの 方向について，効果的に剛性が増加していることが分かる.

\subsection{2 動的振動抑制実験}

本論文では, 対象物が静止している状態での機械拘束自由度 の剛性增加を論議してきた。しかしながら，実際には，持続的 に大きなワイヤ張力を与えることで，動的にも類似の論議が可 能と考えられる。そこで同実験システムを用いて動的剛性増加 についても簡単な実験を行った。

動的実験では，Fig. 15 と同様のワイヤ配置を採用した。また， 効果を比較することを目的として, 駆動が $\alpha, \gamma$ 方向に干涉し 


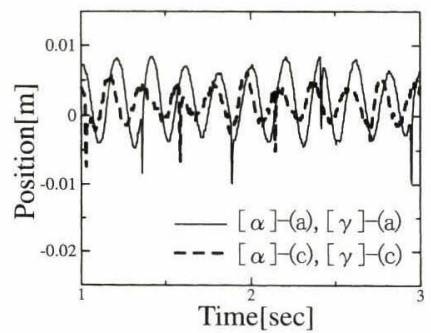

Fig. 18 Dynamic experimental results (Fig. 15 System)

ないワイヤ配置（Fig. $9(\alpha-a, \gamma-a) ） を$ 同時に行った. 本実験で は, 釣り合いワイヤ内力をリアルタイムで与えながら, $\beta$ 回転 に対し, 振幅 $5[\mathrm{deg}]$, 周波数 $5[\mathrm{~Hz}]$ の $\sin$ 波形の目標軌道を与 え, 時変する目標位置に対し, ワイヤ長さをワイヤ座標系制御 法 [12]によって制御した。計測は Fig. 6 のようにPSD カメラ を用い, ロッド先端 $\mathrm{A}$ の位置を $y-z$ 平面に射影して測定した。 横軸に時間を縦軸に $y$ 方向の変位とした実験結果を Fig. 18 に 示す、ロッド先端 $\mathrm{A} の y$ 方向は機械拘束されているため, 本 来変位は常にゼロであるが, $y, \alpha$ 方向の弾性要素により振動 が生じている，インパルス状のセンサノイズが観測されるもの の, 干渉させたワイヤ配置（Fig. 15）の方が駆動が干渉しない ワイヤ配置 (Fig. $9(\alpha-\mathrm{a}, \gamma-\mathrm{a}))$ に比べて, 振動が $50 \%$ 程度に 抑制されているのが分かる。したがって, 本論文で提案する剛 性増加法は動的な場合でも, 有効に作用し, 振動抑制効果があ ることが確認された。

\section{5.おわりに}

本論文では非線形剛性を持つ機械拘束を有するワイヤ駆動に ついて，ワイヤ張力を拘束方向に干渉させることにより，機械 拘束自由度の剛性を増加させる方法を提案した。また，力学的 解析によりワイヤ配置決定法を示した。ささらに, 実際に1 自由 度システムを用いて，実験を行い提案方法の有用性を確かめた。

今回は剛性行列の対角成分のみの効果による剛性増加を論じ た。しかし，機械拘束部材によっては，非対角成分も影響が十 分大きく, 干渉させる自由度よりも, 同時に多くの自由度の剛
性を増加できる場合がある。また，本論文では干渉する力の方 向のみについて論議した。いわば干渉方向の定性的なチェック である，実際には定量的観点から効率のよいワイヤ配置を検討 する必要がある。これらの問題は今後の課題としたい。

\section{参 考 文 献}

[1] T .Higuchi, and A. Ming: "Study on Multiple Degree-ofFreedom Positive Mechanism Using Wires," Proceeding of Asian Conference on robotics and its application, pp.101-106, 1991.

[2] 大隅久, 新井民夫, 浅間一：“3 本ワイヤを有する 7 自由度クレーンの 開発（第 1 報)”，精密工学会誌, vol.59, no.5, pp.767-772, 1993.

[3] 本間敬子, 新井健生：“パラレルメカニズムを用いた上肢動作補助機 構”, 日本ロボット学会誌, vol.15, no.1, pp.90-96, 1997.

[4] S. Kawamura, W. Choe, S. Tanaka, and S.R. Pandian: "Development of an Ultrahigh Speed Robot FALCON using Wire Drive System," IEEE Int. Conf. on Robotics and Automation, pp.215-220, 1995 .

[5] 川村貞夫, 崔源, 田中訓, 木野仁：“パラレルワイヤ駆動方式を用い た超高速ロボットFALCONの開発”，日本ロボット学会誌，vol.15， no.1, pp.82-89, 1997.

[6] Z. Li, H. Chen, H. Kino, and S. Kawamura: "Effect of Internal Force on Stiffness of Antagonized rotational drive mechanism," Proc. of AMSMA, pp.241-245, 2000.

[ 7 ] W. Choe, H. Kino, K. Katsuta, and S. Kawamura: "A Design of Parallel Wire Driven Robots for Ultrahigh Speed Motion Based on Stiffness Analysis," Proc. of The JAPAN-USA Symposium on Flexible Automation, pp.159-166, 1996.

[8 ] 花房, M.A. Adli：“閉じた機構の剛性に及ほす内力の効果”, 日本口 ボット学会誌, vol.10, no.1, pp.128-134, 1992.

[9] 山本元司, 柳井法貴, 毛利彰: “多自由度クレーシ型マニピュレー 夕の逆動力学計算と軌道制御”, 日本ロボット学会誌, vol.17, no.7, pp.1037-1047, 1999.

[10] V.D. Nguyen: "Constructing Force-Closure Grasp in 3D," Proc. of the 1987 IEEE Int. Conf. on Robotics and Automation, pp.240-245, 1987.

[11] 内倉義景, 木野仁, 川村貞夫：“パラレルワイヤ駆動型シリアルリン ク構造ロボットの開発”, 日本機械学会ロボティクスメカトロニクス 講演会, 1998 .

[12] 川村貞夫, 木野仁, 崔源, 勝田兼：“パラレルワイヤ駆動システムに扮 けるワイヤ座標系制御法”, 日本ロボット学会誌, vol.16, no.4, pp.546-552, 1998 .

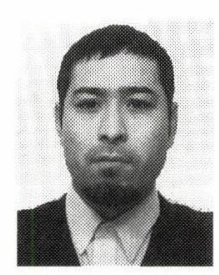

ว.

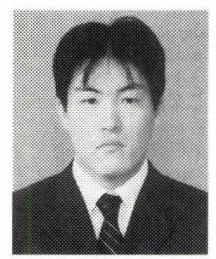

木野 仁 (Hitoshi Kino)

1971 年 3 月 13 日生. 1994 年立命館大学理工学 部機械工学科卒業. 96 年同大学大学院理工学研究 科修士課程修了. 同年同大学大学院博士後期課程 に入学. 97 年 3 月退学後, 滋賀医科大学教務職員 を経て，2001 年 4 月より福岡工業大学講師。パラ レルメカニズム, 医療福祉ロボットなどに興味を持 (日本ロボット学会正会員)

島本武史 (Takeshi Shimamoto)

1977 年 10 月 6 日生. 2000 年立命館大学理工学 部ロボティクス科卒業. 同年同大学大学院理工学研 究科情報システム学専攻修士課程に入学. 現在に至 る。ヴァーチャルリアリティ, マスタースレーブシ ステムの開発に興味を持つ。

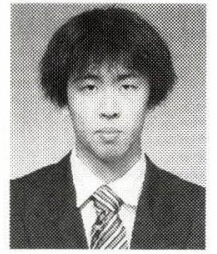

矢部 茂 (Shigeru Yabe)

1976 年 3 月 2 日生. 1999 年立命館大学理工学部 機械工学科卒業. 同年同大学大学院理工学研究科情 報システム学専攻修士課程に入学. 現在に至る. 宇 宙ロボットの開発に興味を持つ。

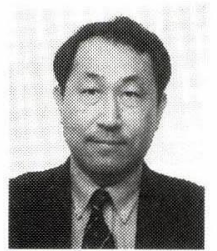

川村貞夫 (Sadao Kawamura)

1956 年 7 月 10 日生. 1981 年大阪大学基礎工学部 生物工学科卒業. 86 年同大学大学院機械工学科博 士課程修了. 同年同大学同学科助手. 87 年立命館 大学理工学部機械工学科助教授を経て, 95 年同大 学同学科教授. 96 年同大学ロボティクス学科教授. 学習制御, 生体ロボティクス等の研究に従事. 日本 機械学会, 計測自動制御学会, システム制御情報学会, IEEE などの 会員. 